\title{
Case Studies and Literature Review of Pneumococcal Septic Arthritis in Adults
}

\author{
Amandine Dernoncourt, ${ }^{1}$ Youssef El Samad, Jean Schmidt, Jean Philippe Emond, \\ Charlotte Gouraud, Anne Brocard, Mohamed El Hamri, Claire Plassart, \\ Florence Rousseau, Valéry Salle, Momar Diouf, Emmanuelle Varon, Farida Hamdad1
}

\section{Medscape ACTIVITY}

In support of improving patient care, this activity has been planned and implemented by Medscape, LLC and Emerging Infectious Diseases. Medscape, LLC is jointly accredited by the Accreditation Council for Continuing Medical Education (ACCME), the Accreditation Council for Pharmacy Education (ACPE), and the American Nurses Credentialing Center (ANCC), to provide continuing education for the healthcare team.

Medscape, LLC designates this Journal-based CME activity for a maximum of 1.00 AMA PRA Category 1 Credit(s) ${ }^{\mathrm{TM}}$. Physicians should claim only the credit commensurate with the extent of their participation in the activity.

Successful completion of this CME activity, which includes participation in the evaluation component, enables the participant to earn up to $1.0 \mathrm{MOC}$ points in the American Board of Internal Medicine's (ABIM) Maintenance of Certification (MOC) program.

Participants will earn MOC points equivalent to the amount of CME credits claimed for the activity. It is the CME activity provider's responsibility to submit participant completion information to ACCME for the purpose of granting ABIM MOC credit.

All other clinicians completing this activity will be issued a certificate of participation. To participate in this journal CME activity: (1) review the learning objectives and author disclosures; (2) study the education content; (3) take the post-test with a $75 \%$ minimum passing score and complete the evaluation at http://www.medscape.org/journal/eid; and (4) view/print certificate. For CME questions, see page 2003.

Learning Objectives

Release date: September 12, 2019; Expiration date: September 12, 2020

Upon completion of this activity, participants will be able to:

- Describe clinical and epidemiological features of pneumococcal SA in adults $>18$ years old reported to the "Picardie Regional Pneumococcal Network" from January 2005 to December 2016, according to results from a retrospective case series and literature review

- Determine diagnosis and treatment of pneumococcal SA in adults $>18$ years old reported to the "Picardie Regional Pneumococcal Network" from January 2005 to December 2016, according to results from a retrospective case series and literature review

- Identify outcomes and implications of pneumococcal SA in adults $>18$ years old reported to the "Picardie Regional Pneumococcal Network" from January 2005 to December 2016, according to results from a retrospective case series and literature review

\section{CME Editor}

Amy J. Guinn, BA, MA, Copyeditor, Emerging Infectious Diseases. Disclosure: Amy J. Guinn, BA, MA, has disclosed no relevant financial relationships.

CME Author

Laurie Barclay, MD, freelance writer and reviewer, Medscape, LLC. Disclosure: Laurie Barclay, MD, has disclosed no relevant financial relationships.

\section{Authors}

Disclosures: Amandine Dernoncourt, MD; Youssef El Samad, MD; Jean Schmidt, MD, PhD; Jean Philippe Émond, PhD; Charlotte Gouraud, MD; Anne Brocard, PharmD; Mohamed El Hamri, MD; Claire Plassart, MD; Florence Rousseau, PharmD, PhD; Valéry Salle, MD, PhD; Momar Diouf, PhD; and Farida Hamdad, PharmD, PhD, have disclosed no relevant financial relationships. Emmanuelle Varon, MD, MSc, has disclosed the following relevant financial relationships: support to attend European Congress of Clinical Microbiology \& Infectious Diseases and European Society for Pediatric Infectious Diseases from Pfizer Inc.
\end{abstract}

Author affiliations: Amiens-Picardie University Medical Center, Amiens, France (A. Dernoncourt, Y. El Samad, J. Schmidt, J.P. Emond, A. Brocard, M. El Hamri, C. Plassart, F. Rousseau, V. Salle, M. Diouf, F. Hamdad); Compiègne Hospital, Compiègne, France (J.P. Emond, C. Gouraud); Senlis Hospital, Senlis, France (A. Brocard); Laon Hospital, Laon, France (M. El Hamri); Beauvais
Hospital, Beauvais, France (C. Plassart); Intercommunal Hospital of Creteil, Paris, France (E. Varon)

DOI: https://doi.org/10.3201/eid2510.181695

${ }^{1}$ These authors contributed equally to this article. 
We conducted a retrospective study on all cases of pneumococcal septic arthritis (SA) in patients $\geq 18$ years of age reported to the Picardie Regional Pneumococcal Network in France during 2005-2016. Among 1,062 cases of invasive pneumococcal disease, we observed 16 (1.5\%) SA cases. Although SA is uncommon in adult patients, the prevalence of pneumococcal SA in the Picardie region increased from $0.69 \%$ during $2005-2010$ to $2.47 \%$ during $2011-2016$ after introduction of the pneumococcal 13 -valent conjugate vaccine. We highlight the emergence of SA cases caused by the 23B serotype, which is not covered in the vaccine.

Neptic arthritis (SA) constitutes a medical emergency $\checkmark$ and is associated with high rates of illness and death $(1-3)$. The annual incidence of proven or probable SA in industrialized countries is $4-10 / 100,000$ patients in the general population and 30-70/100,000 in patients with rheumatoid arthritis or history of prosthetic joint replacement surgery (1-3). The increasing prevalence over recent decades is related to an aging population, use of immunosuppressive drugs, and the growing number of orthopedic procedures (1-3). Large studies of SA have identified Staphylococcus aureus as the most common is organism involved, along with Streptococcus pyogenes to a lesser degree (1-4). Streptococcus pneumoniae is considered an uncommon cause of SA in adults (3-11).

S. pneumoniae is a common cause of bacterial community-acquired pneumonia, acute otitis, maxillary sinusitis, and severe invasive infections, especially in patients $<2$ or $\geq 65$ years of age and in patients with underlying conditions, such as diabetes, malignancy, immune deficiency, chronic alcoholism, and splenectomy (12-15). Invasive pneumococcal disease (IPD) is a major public health concern worldwide, with a reported incidence of 7-97/100,000 persons $\geq 18$ years of age annually (14). IPD is defined as isolation of pneumococci from normally sterile body fluids. According to a review from 1952-2008, pneumococcal SA occurred in $0.6 \%-2.2 \%$ of all cases of IPD (14). Similarly, in a large case study published by Marrie et al. (16), 1.6\% of patients with IPD had pneumococcal SA.

Antimicrobial drug therapy and vaccination have been central elements of the clinical approach to pneumococcal disease. Literature from the 1990s also emphasized the spread of pneumococcal strains resistant to $\beta$-lactams and other antimicrobial agents $(1,2,5-10,12-15)$. Pneumococcal vaccination has since become a global public health focus $(15,17-21)$.

We analyzed all cases of pneumococcal SA in patients $\geq 18$ years of age reported to the Picardie Regional Pneumococcal Network in France during 2005-2016. We also reviewed scientific publications on SA from the 1950s through 2017. Our aim was to the determine prevalence of $S$. pneumoniae in SA and assess whether introduction of pneumococcal 13-valent conjugate vaccine (PCV13) might contribute to increased rates of pneumococcal SA.

\section{Patients and Methods}

The Picardie region of France has a population of $\approx 2$ million. Cases of IPD are reported to the Picardie Regional Pneumococcal Network, a collection of 12 public hospitalbased clinical bacteriology departments across the region. We conducted a retrospective study of pneumococcal SA in patients $\geq 18$ years of age reported to the network during January 1, 2005-December 31, 2016. We defined cases by either an $S$. pneumoniae-positive culture from synovial fluid, an S. pneumoniae-positive blood culture with purulent or inflammatory joint fluid, medical imaging consistent with the diagnosis of arthritis, or a combination of these.

We collected patient demographic characteristics, including age, sex, and underlying conditions; clinical signs and symptoms; whether patients had other sites of pneumococcal infection; laboratory findings; antimicrobial therapy; and clinical outcomes. We performed statistical analyses by using SAS version 9.4 (SAS Institute Inc., https://www.sas.com) software, and estimated $p$ values for comparison of relative frequencies by using $\chi^{2}$ test. We considered $\mathrm{p}<0.05$ the threshold for statistical significance. This study was conducted in compliance with French legislation and the Declaration of Helsinki regarding ethics principles for medical research involving human subjects.

We also conducted a review of the largest case studies ( $\geq 3$ patients) of pneumococcal SA in patients $\geq 18$ years of age published in the medical literature during 1950-2017 by using the search terms "Streptococcus pneumoniae infection" and "Septic arthritis" in the PubMed database. We excluded studies reporting on patients $<18$ years of age, in vitro and animal studies, and other factors. We retrieved 15 studies for full-text review and identified 7 studies meeting our inclusion criteria (Figure).

\section{Results}

During January 1, 2005-December 31, 2016, we observed $16(1.5 \%)$ cases of pneumococcal SA out of 1,062 cases of IPD reported (Table 1). The prevalence of pneumococcal SA increased during the study period, ranging from $0.69 \%$ during 2005-2010 to $2.47 \%$ during 2011-2016 ( $p=0.02$ ).

Of patients with pneumococcal SA, the mean age was 69.7 (34-93) years, and $62.5 \%$ were $\geq 65$ years of age; 9 were women and 7 were men. Fourteen $(87.5 \%)$ patients had monoarticular infection; the other $2(12.5 \%)$ cases had polyarticular infection, 1 case involving the knee and shoulders and the other sacroiliac joints.

For 14 patients, data on medical history, clinical characteristics, and time to diagnosis were available (Table 2). We found that $11(78.57 \%)$ patients had 1-2 underlying 


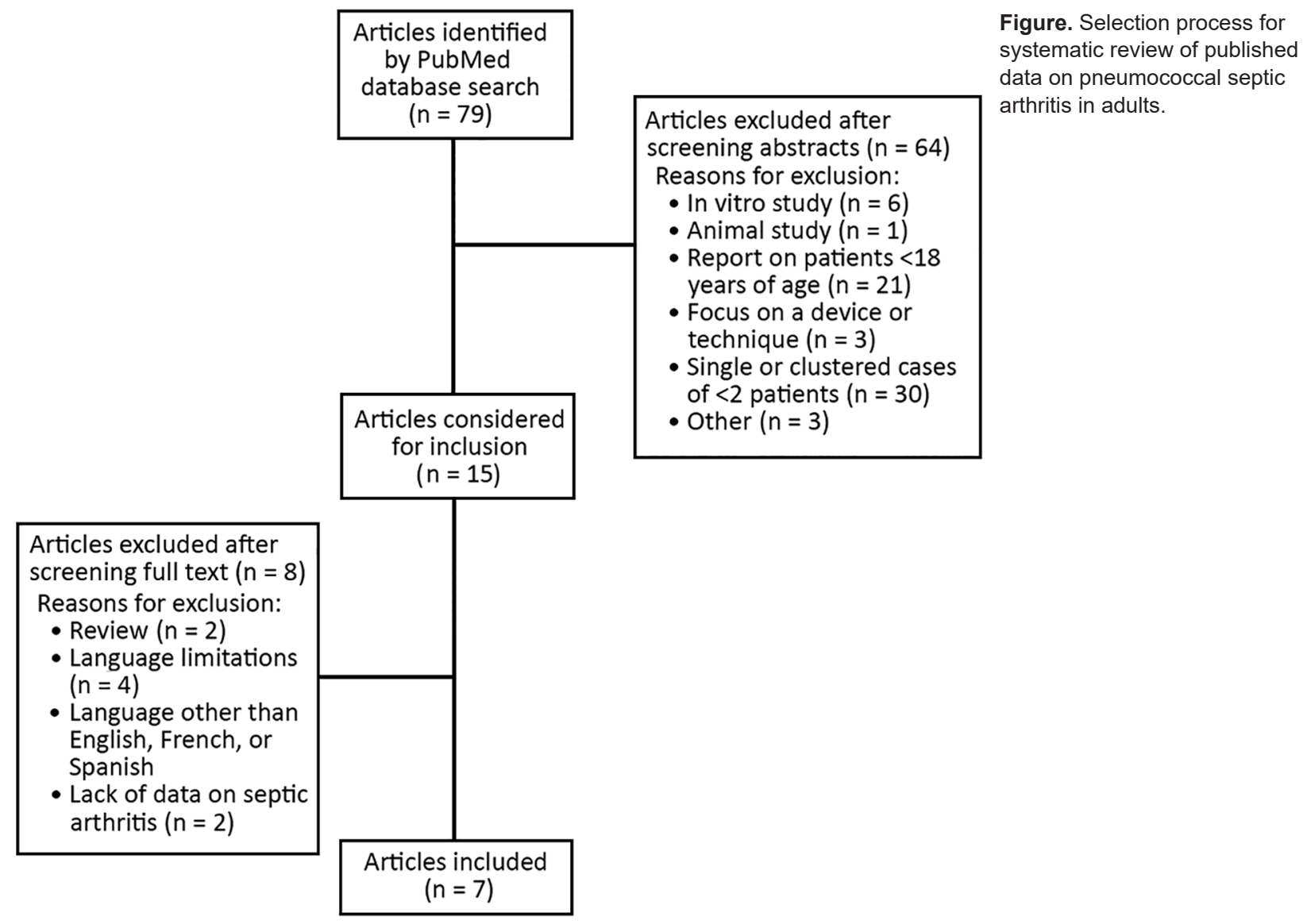

conditions predisposing them to pneumococcal SA, 5 (35.71\%) had 1 condition, and $6(42.86 \%)$ had $>1$ condition; $3(21.42 \%)$ had no risk factors but were among the oldest patients, and $5(35.71 \%)$ had concurrent respiratory tract infections. Most joint infections involved the knee, $11 / 16(68.75 \%)$ SA cases; 9 (56.25\%) patients had native joint infections; and $5(31.25 \%)$ patients had infections after prosthetic joint surgery, 4 involving a knee and 1 involving a hip.

Of note, 1 patient had undergone surgery for inguinal hernia, which was complicated by abdominal wall hematoma and pneumococcal SA with concomitant crystal-induced arthritis (gout). Another patient received a diagnosis of multiple myeloma while hospitalized for pneumococcal SA. An additional patient developed pneumococcal SA 2 years after the joint infection.

Vaccination status was available for $11(78.57 \%)$ of the 14 patients with clinical data. Only 2 patients had been vaccinated against pneumococci, both after splenectomy.
Two patients were admitted to the intensive care unit with septic shock and severe renal failure. All patients reported pain of the infected joint; only half were febrile $\left(>38^{\circ} \mathrm{C}\right)$ at admission; and $10(71.42 \%)$ patients had joint swelling. The median interval between admission and diagnosis was 1 day (range 1-60 days). The patient with infection of the prosthetic hip joint had few symptoms, which might explain the delay in diagnosis of pneumococcal SA, which took 60 days.

Leukocyte scintigraphy was helpful for 3 patients, 1 with prosthetic hip joint infection and 2 with sacroiliac joint infection. Positron emission tomography was performed for a patient with infection of a single sacroiliac joint, which showed increased radionuclide uptake.

We noted increased white cell count, $>10,000 / \mathrm{mm}^{3}$, in $13(81.25 \%)$ cases with a mean of 13,800 cells $/ \mathrm{mm}^{3}$ (range 6,020-78,000 cells $/ \mathrm{mm}^{3}$ ). Fourteen patients had serum Creactive protein (CRP) results, and $13(92.82 \%)$ had CRP $>100 \mathrm{mg} / \mathrm{L}$ (mean $325 \mathrm{mg} / \mathrm{L}$ [range 28-552 mg/L]) (Table

\begin{tabular}{lcccccccccccc}
\hline Table 1. Cases of septic arthritis and IPD, Picardie region, France, $2005-2016^{*}$ \\
\hline Year & 2005 & 2006 & 2007 & 2008 & 2009 & 2010 & 2011 & 2012 & 2013 & 2014 & 2015 & 2016 \\
\hline IPD cases, no. & 130 & 39 & 108 & 92 & 141 & 67 & 83 & 58 & 106 & 60 & 89 & 89 \\
No. (\%) pneumococcal SA & 0 & 0 & $3(2.8)$ & 0 & 0 & $1(1.5)$ & $1(1.2)$ & $3(5.2)$ & $1(0.9)$ & $2(3.3 \%)$ & 0 & $5(5.6)$ \\
\hline
\end{tabular}

${ }^{*} \mathrm{IPD}$, invasive pneumococcal disease; SA, septic arthritis 
Table 2. Demographic data, clinical characteristics, underlying conditions, and other sites of pneumococcal infection for 16 patients with pneumococcal septic arthritis in the Picardie region, France, 2005-2016*

\begin{tabular}{|c|c|c|c|c|c|c|}
\hline $\begin{array}{l}\text { Patient } \\
\text { age, y/sex }\end{array}$ & Affected joint & $\begin{array}{c}\text { Days from admission } \\
\text { to diagnosis }\end{array}$ & $\begin{array}{l}\text { Underlying conditions, } \\
\text { risk factors }\end{array}$ & $\begin{array}{c}\text { Vaccination, } \\
\text { type }\end{array}$ & $\begin{array}{c}\text { Clinical signs and } \\
\text { symptoms }\end{array}$ & Other infection \\
\hline $90 / \mathrm{M}$ & $\begin{array}{c}\text { Hip, prosthetic joint } \\
\text { surgery } 1 \text { y before } \\
\text { SA }\end{array}$ & 60 & $\begin{array}{c}\text { Multiple myeloma } \\
\text { diagnosed } 2 \text { y after septic } \\
\text { arthritis }\end{array}$ & ND & Joint pain & None \\
\hline $93 / F$ & $\begin{array}{c}\text { Knee, prosthetic } \\
\text { joint surgery } 5 \text { y } \\
\text { before SA }\end{array}$ & 2 & None & ND & $\begin{array}{l}\text { Joint pain and } \\
\text { swelling }\end{array}$ & Pneumonia \\
\hline $34 / \mathrm{M}$ & Hip & 1 & Chronic alcoholism & $\mathrm{N}$ & Fever, joint pain & None \\
\hline $68 / \mathrm{M}$ & Knee & 4 & Gout, heart disease & $\mathrm{N}$ & $\begin{array}{l}\text { Fever, joint pain } \\
\text { and swelling }\end{array}$ & $\begin{array}{c}\text { Hematoma in } \\
\text { abdominal } \\
\text { muscles }\end{array}$ \\
\hline $75 / \mathrm{M}$ & Knee & 1 & $\begin{array}{l}\text { Diabetes mellitus, heart } \\
\text { disease }\end{array}$ & $\mathrm{N}$ & $\begin{array}{c}\text { Joint pain and } \\
\text { swelling }\end{array}$ & None \\
\hline $42 / F$ & $\begin{array}{c}\text { One knee, both } \\
\text { shoulders }\end{array}$ & 1 & $\begin{array}{c}\text { Splenectomy, } \\
\text { Immunosuppressive drug }\end{array}$ & Y, PPV23 & $\begin{array}{c}\text { Joint pain and } \\
\text { swelling }\end{array}$ & None \\
\hline $80 / F$ & Knee & 1 & Chronic alcoholism & $\mathrm{N}$ & $\begin{array}{l}\text { Joint pain and } \\
\text { swelling }\end{array}$ & None \\
\hline $61 / F$ & Knee & 2 & $\begin{array}{c}\text { COPD, multiple myeloma } \\
\text { diagnosed while } \\
\text { hospitalized for septic } \\
\text { arthritis }\end{array}$ & $\mathrm{N}$ & $\begin{array}{l}\text { Fever, joint pain } \\
\text { and swelling }\end{array}$ & None \\
\hline $57 / F$ & Shoulder & 1 & COPD, MGUS & $\mathrm{N}$ & $\begin{array}{l}\text { Joint pain and } \\
\text { swelling }\end{array}$ & $\begin{array}{l}\text { Bronchitis } 3 \\
\text { weeks prior }\end{array}$ \\
\hline $82 / F$ & $\begin{array}{l}\text { Knee, prosthetic } \\
\text { joint }\end{array}$ & ND & ND & ND & ND & ND \\
\hline $90 / \mathrm{F}$ & Knee & ND & ND & ND & ND & ND \\
\hline $53 / F$ & $\begin{array}{l}\text { Both sacroiliac } \\
\text { joints }\end{array}$ & 2 & Splenectomy & Y, PCV13 & Fever, joint pain & $\begin{array}{c}\text { Sinusitis } 3 \\
\text { weeks prior }\end{array}$ \\
\hline $69 / M$ & $\begin{array}{c}\text { Knee, prosthetic } \\
\text { joint surgery } 1 \text { mo } \\
\text { before SA }\end{array}$ & 1 & $\begin{array}{l}\text { Malignant disease } \\
\text { MGUS }\end{array}$ & $\mathrm{N}$ & $\begin{array}{l}\text { Fever, joint pain } \\
\text { and swelling }\end{array}$ & None \\
\hline $82 / F$ & $\begin{array}{c}\text { Knee, prosthetic } \\
\text { joint surgery } 1 \mathrm{y} \\
\text { before SA }\end{array}$ & 1 & None & $\mathrm{N}$ & $\begin{array}{l}\text { Fever, joint pain } \\
\text { and swelling }\end{array}$ & Pneumonia \\
\hline $57 / \mathrm{M}$ & Knee & 1 & Chronic alcoholism & ND & $\begin{array}{l}\text { Fever, joint pain } \\
\text { and swelling }\end{array}$ & None \\
\hline $82 / \mathrm{M}$ & Sacroiliac joint & 5 & None & $\mathrm{N}$ & Joint pain & Pneumonia \\
\hline
\end{tabular}

3 ). Procalcitonin test (PCT) was performed on 8 patients, and $6(75 \%)$ had levels $>0.5 \mathrm{ng} / \mathrm{mL}$. Urinary pneumococcal antigen detection was performed for 5 patients, and 4 $(80 \%)$ patients had positive results.

Joint aspiration was performed in 15 cases; a patient with sacroiliac joint SA was excluded. All joint aspirates had white blood cell counts $>10,000 / \mathrm{mm}^{3}$ on cytological analysis and were purulent in $10(66.67 \%)$ cases. Gram staining showed gram-positive cocci in $11(73.33 \%)$ cases. Joint fluid was cultured for S. pneumoniae, and $14(93.33 \%)$ cases had positive cultures; $S$. pneumoniae strains were recovered from both joint aspirate and blood cultures from 9 (56.25\%) cases. In 2 (12.5\%) cases, bacteriological diagnosis of arthritis was made exclusively on the basis of blood culture, and in $5(31.25 \%)$ cases, the positive culture was only obtained for joint aspirate.

Of the 16 S. pneumoniae strains we recovered, $4(25 \%)$ had low-level penicillin resistance, $1(6.25 \%)$ also had lowlevel ceftriaxone resistance, and 1 (6.25\%) had high-level ceftriaxone resistance (MIC $4 \mathrm{mg} / \mathrm{L})$. Three $(75 \%)$ of 4 strains from 2005-2010 had low-level penicillin resistance, whereas only $1(8.3 \%)$ of 12 strains from 2011-2016 had low-level penicillin resistance $(\mathrm{p}<0.01)$. All strains isolated from cases of nonbacteremic SA were penicillin susceptible. We serotyped 15 isolates and found $33.33 \%$ were strain $23 \mathrm{~B}, 13.33 \%$ were $19 \mathrm{~F}$, and $13.33 \%$ were serotype 1 (Table 3). Serotype 23B was always penicillin susceptible, but other the serotypes had low-level penicillin resistance.

All patients were treated with a combination of 2 intravenous antimicrobial drugs, mainly amoxicillin and gentamicin (68.75\%). The median duration for intravenous antimicrobial therapy was 6 days (range 1-27 days). After intravenous antimicrobial drug therapy, patients were prescribed oral antimicrobial drugs, such as amoxicillin, rifampin, levofloxacin, or clindamycin, alone or in combination (Table 4). The median overall duration of antimicrobial therapy was 42 days (range 42-84 days) for patients with native joint infection and 47 days (range 42-120 days) for patients with infection in prosthetic joints. In addition to antimicrobial therapy, all patients with prosthetic joint 
Table 3. Laboratory findings, joint analysis, antimicrobial susceptibility, and serotypes of Pneumococcus-positive cultures for 16 patients with pneumococcal septic arthritis, Picardie region, France, 2005-2016*

\begin{tabular}{|c|c|c|c|c|c|c|c|c|c|c|c|c|}
\hline \multirow{2}{*}{$\begin{array}{l}\text { Patient } \\
\text { age, y/sex }\end{array}$} & \multicolumn{5}{|c|}{ Laboratory findings } & \multicolumn{3}{|c|}{ Joint analysis } & \multicolumn{3}{|c|}{$\mathrm{MIC}, \mathrm{mg} / \mathrm{L}$} & \multirow[b]{2}{*}{ Serotype } \\
\hline & CRP† & Leuk $\ddagger$ & PCT§ & Bact & $\mathrm{Ag} \mathrm{U}$ & Characteristics & Gram stain & Culture & PEN & AMOX & CEF & \\
\hline 90/M & 100 & 10,400 & 0.14 & $\mathrm{Y}$ & + & Inflammation & - & + & 2 & 2 & 0.5 & $19 \mathrm{~F}$ \\
\hline $93 / F$ & 505 & 11,900 & 5.6 & Y & + & Purulent & + & + & 0.016 & 0.016 & 0.016 & 3 \\
\hline $34 / \mathrm{M}$ & 290 & 14,000 & 0.36 & $\mathrm{~N}$ & NA & Purulent & + & + & 0.016 & 0.016 & 0.016 & $10 \mathrm{~A}$ \\
\hline $68 / \mathrm{M}$ & 28 & 78,000 & NA & Y & NA & Purulent & + & + & 0.5 & 0.25 & 0.25 & 1 \\
\hline $75 / \mathrm{M}$ & 360 & 13,800 & NA & Y & NA & Purulent & + & + & 0.064 & 0.016 & 0.016 & NA \\
\hline $42 / F$ & 203 & 44,000 & 13 & $\mathrm{Y}$ & NA & Inflammation & - & + & 0.016 & 0.016 & 0.016 & 23BT \\
\hline $80 / F$ & 385 & 18,200 & NA & Y & NA & Purulent & + & + & 0.016 & 0.016 & 0.032 & 23Bग \\
\hline $61 / F$ & 552 & 6,020 & 155 & Y & NA & Purulent & + & + & 0.5 & 0.5 & 1 & 1 \\
\hline $57 / F$ & 391 & 11,310 & NA & $\mathrm{N}$ & NA & Inflammation & NA & + & 0.008 & 0.016 & 0.016 & 23B \\
\hline $82 / F$ & NA & 12,200 & NA & $\mathrm{N}$ & NA & Inflammation & + & + & 0.016 & 0.016 & 0.032 & 6A\# \\
\hline $90 / F$ & NA & NA & NA & Y & + & Purulent & + & - & 1 & 0.5 & 4 & $19 \mathrm{~F}$ \\
\hline $53 / F$ & 110 & 12,800 & 69.9 & Y & - & NA & NA & NA & 0.016 & 0.016 & 0.016 & 24Fף \\
\hline 69/M & 552 & 8,740 & NA & Y & NA & Purulent & + & + & 0.016 & 0.016 & 0.016 & $9 N$ \\
\hline $82 / F$ & 178 & 19,480 & 3.72 & Y & NA & Purulent & + & + & 0.016 & 0.016 & 0.016 & 8 \\
\hline $57 / M$ & 450 & 15,550 & NA & $\mathrm{N}$ & NA & Purulent & - & + & 0.032 & 0.016 & 0.016 & 23Bף \\
\hline $82 / \mathrm{M}$ & 240 & 21,000 & 0.96 & $\mathrm{~N}$ & + & Inflammation & + & + & 0.016 & 0.016 & 0.016 & 23B \\
\hline $\begin{array}{l}{ }^{*} \mathrm{Ag} U, \mathrm{pneu} \\
\text { available; Pc } \\
\text { vaccine; +, } \mathrm{p} \\
\text { †In } \mathrm{mg} / \mathrm{L} . \\
\text { †ln cells/mm } \\
\text { §ln ng/mL. } \\
\text { TSerotypes } \\
\text { \#Serotype c }\end{array}$ & cover & y PCV & or PP & 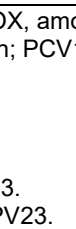 & illin; & & 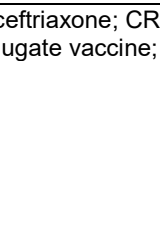 & S-pr & & & tes; $N$ & \\
\hline
\end{tabular}

infection also underwent surgical drainage, and 1 patient also required replacement of the prosthetic hip joint.

Most patients survived, but $1(6.25 \%)$ patient died from colchicine-related multiorgan failure 2 days after admission. The remaining patients recovered well $8(57.14 \%)$ of 14 patients completely recovered, and $5(35.71 \%)$ had moderately reduced range of motion in the affected joint (Table 4).

\section{Literature Review}

We reviewed the largest case studies published during 1950-2017 (Table 5) and identified 121 cases of S. pneumoniae SA in adults in the literature $(4,6-10,16)$. The age of affected patients was $47-75$ years. Case-patients included 71 men and 50 women, 87.6\% (106/121) of whom had underlying conditions that might have been predisposing factors for pneumococcal SA, including rheumatoid arthritis, gout and degenerative joint disease, diabetes, alcoholism, immunosuppression, cardiovascular disease, chronic obstructive pulmonary disease, malignancy, corticosteroid use, and splenectomy.

The clinical characteristics of pneumococcal infection, laboratory findings, antimicrobial therapy, and clinical outcomes were not available for all cases, and immunization status rarely was described. Among 70 patients for whom clinical characteristics were available, $36(51.42 \%)$ had either prior or concurrent pneumococcal infections other than SA, including $24(35.71 \%)$ cases of pneumonia, 10 $(14.29 \%)$ cases of meningitis, and 4 (5.71\%) cases of endocarditis. The knee was the joint most commonly involved in SA (66/121), but other affected sites included the shoulder
(19/105), ankle (11/105), hip (10/112), and elbow (9/105). Polyarticular involvement was reported in $23 \%$ of patients (28/121). Of 70 patients with prosthetic joint replacement, $4(5.71 \%)$ had S. pneumoniae infections and 61 (87.14\%) had joint cultures that were positive for bacteremia.

Concomitant bacteremia was documented in 98/119 $(82.35 \%)$ patients for whom blood culture results were reported. Of 59 documented isolates, $5(8.47 \%)$ demonstrated low-level penicillin resistance and $3(5.1 \%)$ had low-level ceftriaxone resistance. Serotype data were seldom available, but a study by Marrie et al. (16) listed serotypes 4, 8, and $22 \mathrm{~F}$ as the most commonly isolated.

Of the 121 patients we identified, 117 (96.7\%) received antimicrobial therapy. Of those, 41 cases had detailed data on treatment regimens. Penicillin was the first-line treatment in $29(70.7 \%)$ cases; third-generation cephalosporins, vancomycin, and rifampin were administered less frequently.

Among the 63 patients for whom clinical outcome data were available, 58 (92.1\%) underwent joint drainage, and $11.1 \%-66.7 \%$ experienced sequelae of the joint infection. Death rates were variable among the studies but ranged as high as $32 \%$.

\section{Discussion}

We report $16(1.5 \%)$ cases of pneumococcal SA in a cohort of 1,062 IPD patients in France. Our study only includes data on $S$. pneumoniae-positive cultures from patients who were treated in public-sector hospitals. The true number of cases of pneumococcal SA in the region likely would be higher if data from private-sector hospitals were included. We found that the prevalence 
Table 4. Clinical data on 16 patients with pneumococcal septic arthritis, Picardie region, France, 2005-2016*

\begin{tabular}{|c|c|c|c|c|c|}
\hline $\begin{array}{l}\text { Patient age, } \\
\text { y/sex }\end{array}$ & $\begin{array}{l}\text { Antimicrobial drugs, initial } \\
\text { intravenous therapy; duration, } d\end{array}$ & $\begin{array}{l}\text { Antimicrobial drugs, } \\
\text { change to oral therapy }\end{array}$ & $\begin{array}{c}\text { Surgical } \\
\text { intervention }\end{array}$ & $\begin{array}{l}\text { Duration of } \\
\text { antimicrobial } \\
\text { therapy, d }\end{array}$ & Clinical outcome \\
\hline 90/M & Ceftriaxone and rifampin; 4 & $\begin{array}{l}\text { Levofloxacin and } \\
\text { rifampin }\end{array}$ & $\begin{array}{l}\text { Arthrotomy and } \\
\text { replacement of } \\
\text { prosthetic joint }\end{array}$ & 42 & $\begin{array}{l}\text { Recovered, regained } \\
\text { baseline joint function }\end{array}$ \\
\hline 93/F & Ceftriaxone and gentamicin; 5 & $\begin{array}{l}\text { Levofloxacin and } \\
\text { clindamycin }\end{array}$ & $\begin{array}{l}\text { Arthrotomy and } \\
\text { synovectomy }\end{array}$ & 120 & $\begin{array}{l}\text { Recovered, regained } \\
\text { baseline joint function }\end{array}$ \\
\hline $34 / \mathrm{M}$ & Amoxicillin and gentamicin; 4 & $\begin{array}{l}\text { Levofloxacin and } \\
\text { amoxicillin }\end{array}$ & None & 42 & $\begin{array}{l}\text { Recovered, moderately } \\
\text { reduced range of motion }\end{array}$ \\
\hline $68 / \mathrm{M}$ & Amoxicillin and gentamicin; 2 & NA & None & 2 & $\begin{array}{c}\text { Died } 2 \mathrm{~d} \text { after admission } \\
\text { from multiorgan failure } \\
\text { related to colchicine } \\
\text { overdose }\end{array}$ \\
\hline $75 / M$ & $\begin{array}{l}\text { Amoxicillin and gentamicin, } \\
\text { then amoxicillin and } \\
\text { levofloxacin; } 11\end{array}$ & Levofloxacin & None & 42 & $\begin{array}{l}\text { Recovered, regained } \\
\text { baseline joint function }\end{array}$ \\
\hline $42 / F$ & Vancomycin and gentamicin; 6 & $\begin{array}{l}\text { Levofloxacin and } \\
\text { rifampin }\end{array}$ & Arthrotomy & 42 & $\begin{array}{l}\text { Recovered, moderately } \\
\text { reduced range of motion }\end{array}$ \\
\hline $80 / F$ & Ofloxacin and cloxacillin; 1 & Amoxicillin & None & 42 & $\begin{array}{l}\text { Recovered, regained } \\
\text { baseline joint function }\end{array}$ \\
\hline $61 / F$ & $\begin{array}{l}\text { Amoxicillin and levofloxacin and } \\
\text { rifampin; } 7\end{array}$ & $\begin{array}{l}\text { Amoxicillin and } \\
\text { rifampin }\end{array}$ & Arthrotomy & 42 & $\begin{array}{l}\text { Recovered, regained } \\
\text { baseline joint function }\end{array}$ \\
\hline $57 / F$ & Amoxicillin and gentamicin; 5 & Amoxicillin & None & 42 & $\begin{array}{l}\text { Recovered, moderately } \\
\text { reduced range of motion }\end{array}$ \\
\hline $82 / \mathrm{F}$ & ND & ND & ND & ND & ND \\
\hline $92 / F$ & ND & ND & ND & ND & ND \\
\hline $53 / F$ & Ceftriaxone and gentamicin; 15 & Levofloxacin & None & 84 & $\begin{array}{l}\text { Recovered, regained } \\
\text { baseline joint function }\end{array}$ \\
\hline 69/M & Amoxicillin and gentamicin; ND & ND & ND & ND & $\begin{array}{l}\text { Recovered, regained } \\
\text { baseline joint function }\end{array}$ \\
\hline $82 / F$ & Cefotaxime and gentamicin; 7 & $\begin{array}{l}\text { Levofloxacin and } \\
\text { rifampin }\end{array}$ & Arthrotomy & 47 & $\begin{array}{l}\text { Recovered, moderately } \\
\text { reduced range of motion }\end{array}$ \\
\hline $57 / \mathrm{M}$ & Amoxicillin and gentamicin; 27 & Amoxicillin & $\begin{array}{l}\text { Arthrotomy and } \\
\text { synovectomy }\end{array}$ & 42 & $\begin{array}{l}\text { Recovered, moderately } \\
\text { reduced range of motion }\end{array}$ \\
\hline $82 / \mathrm{M}$ & Amoxicillin and gentamicin; 10 & Amoxicillin & None & 42 & $\begin{array}{l}\text { Recovered, regained } \\
\text { baseline joint function }\end{array}$ \\
\hline
\end{tabular}

of pneumococcal SA reported to the Picardie Regional Pneumococcal Network increased 4-fold after introduction of PCV13 in 2010.

We observed slight female predominance in our casepatients, which is in line with other studies $(8,9)$. However, some studies describe male predominance $(4,7,10,16)$. We found that older adults were more susceptible to pneumococcal SA; $62.5 \%$ of our patients were $\geq 65$, but this proportion was lower than reported in previous studies $(4,6-$ $10,16,22)$. Underlying conditions that could predispose patients to pneumococcal SA were observed in $79 \%$ of cases, and $21 \%$ of pneumococcal joint infections occurred in apparently healthy patients, which is in line with the results reported by others (23).

Among our cohort, 2 cases of multiple myeloma were revealed by pneumococcal SA. Because multiple myeloma causes immunosuppression, patients with multiple myeloma are more likely to become infected by encapsulated bacteria. Clinicians should consider multiple myeloma when pneumococcal SA is diagnosed in patients with no apparent predisposing factor $(24,25)$.
Some studies report a history of concomitant extra-articular infection in $40 \%-60 \%$ of patients with pneumococcal joint infection $(6-8,10)$. We noted pneumococcal respiratory tract infection in $36 \%$ of our cohort, but the respiratory tract was the only site of concomitant extra-articular infection reported. The knee was the joint affected most commonly. Among our cohort, $62.5 \%$ had SA in the knee and $12.5 \%$ had SA in the hip, a site reported less commonly overall; only $1 \%-7.8 \%$ of SA cases in the literature involved the hip $(9,10,26)$. SA involved a prosthetic joint in $31 \%$ of cases, a higher rate than previously reported $(6,7,9,10,26)$. Joint prosthesis in older adults appears to be an added risk factor for SA.

For most patients, the time to diagnosis was a few days. However, the diagnosis of prosthetic joint SA, particularly in the hip, was sometimes longer, as seen in previous findings $(4,9,26)$.

Clinical signs and conventional laboratory markers, such as elevated white blood cell count, and CRP cannot differentiate infectious from noninfectious inflammation, and these tests should not be used alone to diagnose SA. Serum 
Table 5. Detailed analysis of reports of septic arthritis in patients $>18$ years of age reported in medical literature during 1950-2019* Study authors, year published (reference)

\begin{tabular}{|c|c|c|c|c|c|c|c|c|}
\hline \multirow[b]{2}{*}{ Study details } & \\
\hline & This study & $\begin{array}{l}\text { Ros, et al., } \\
2003(10)\end{array}$ & $\begin{array}{l}\text { Ispahani et } \\
\text { al., } 1999(8)\end{array}$ & $\begin{array}{c}\text { Dubost et } \\
\text { al., } 2004(4)\end{array}$ & $\begin{array}{l}\text { Raad et al., } \\
2004(6)\end{array}$ & $\begin{array}{c}\text { James et } \\
\text { al., } 2000 \text { (7) }\end{array}$ & $\begin{array}{c}\text { Belkhir et } \\
\text { al., } 2014(9)\end{array}$ & $\begin{array}{c}\text { Marrie et al., } \\
2017(16) \\
\end{array}$ \\
\hline No. patients & 16 & 11 & 25 & 7 & 4 & 14 & 9 & 51 \\
\hline Median age, y (IQR) & $69.7( \pm 25)$ & $60( \pm 18.5)$ & 69 (NA) & 63 (NA) & $47( \pm 3.25)$ & $63( \pm 21.75)$ & $75( \pm 26)$ & $56( \pm 17)$ \\
\hline Sex, M/F & $7 / \overline{9}^{-1 /}$ & $6 / 5$ & $11 / 14$ & $4 / 3$ & $2 / 2$ & $9 / 5$ & $4 / 5$ & $35 / 16$ \\
\hline \multicolumn{9}{|l|}{ Impaired joints, no. } \\
\hline Knee & 11 & 6 & 12 & 4 & 0 & 10 & 7 & 26 \\
\hline Hip & 2 & 0 & 0 & 0 & 2 & 0 & 0 & 0 \\
\hline$>1$ joint & 2 & 3 & 5 & 0 & 3 & 6 & 0 & 9 \\
\hline Prosthetic joint & 5 & 2 & 2 & 0 & 0 & 0 & 0 & NA \\
\hline $\begin{array}{l}\text { Extraarticular } \\
\text { infections, no. }\end{array}$ & $6 \dagger$ & 5 & 11 & 1 & 2 & 7 & 5 & NA \\
\hline $\begin{array}{l}\text { Underlying conditions, } \\
\text { no. }\end{array}$ & $11 †$ & 9 & 23 & 5 & 4 & 10 & 3 & 48 \\
\hline $\begin{array}{l}\text { Known vaccination } \\
\text { status, no. }\end{array}$ & 11 & 0 & 0 & 0 & 0 & 0 & 1 & 0 \\
\hline No. immunized & 2 & - & - & - & - & - & 0 & - \\
\hline \multicolumn{9}{|c|}{ Laboratory data, no. positive/no. tested } \\
\hline Bacteremia & $11 / 16$ & $9 / 11$ & $20 / 24$ & $4 / 6$ & $1 / 4$ & $8 / 14$ & $5 / 9$ & $51 / 51$ \\
\hline Gram stain & $11 / 14$ & NA & $23 / 25$ & $4 / 5$ & NA & NA & $5 / 9$ & NA \\
\hline Culture & $14 / 15$ & $11 / 11$ & $19 / 25$ & $7 / 7$ & $4 / 4$ & $13 / 14$ & $7 / 9$ & NA \\
\hline Serotypes, no. & 6 & 1 & 1 & NA & NA & NA & 4 & 29 \\
\hline Strains & $\begin{array}{l}\text { 23B and } \\
24 \mathrm{~F}\end{array}$ & $6 \mathrm{~A}$ & $24 \mathrm{~F}$ & - & - & - & NA & NA \\
\hline $\begin{array}{l}\text { Covered by PCV13 } \\
\text { and PPV23 }\end{array}$ & $\mathrm{N}$ & $\mathrm{Y}$ & $\mathrm{N}$ & - & - & - & $\mathrm{Y}$ & \\
\hline \multicolumn{9}{|l|}{ Susceptibility } \\
\hline Penicillin S & 4 & 3 & 25 & NA & 2 & NA & 5 & NA \\
\hline Ceftriaxone S & 1 & 1 & 25 & NA & 1 & 1 & NA & NA \\
\hline Ceftriaxone R & 1 & - & - & - & - & - & NA & NA \\
\hline $\begin{array}{l}\text { Median duration of } \\
\text { antimicrobial therapy, } \mathrm{d}\end{array}$ & 42 & 42 & 49 & 27 & 49 & NA & 44.7 & NA \\
\hline $\begin{array}{l}\text { Surgical intervention, } \\
\text { no.f }\end{array}$ & $6 \dagger$ & $8 \dagger$ & 21 & 3 & 2 & 11 & 6 & NA \\
\hline \multicolumn{9}{|l|}{ Clinical outcome } \\
\hline Death & 1 & 2 & 8 & 0 & 0 & 3 & 1 & 6 \\
\hline Sequelae & 5 & 4 & 10 & 4 & 1 & 2 & 1 & NA \\
\hline
\end{tabular}

PCT levels also increase in various forms of inflammation and microbial infections. PCT is $<0.5 \mathrm{ng} / \mathrm{mL}$ in healthy patients but rapidly increases with systemic bacterial infections, such as SA (27). Some studies have reported falsely low PCT during the early phase of infection or in localized infections, such as SA (27). In our study, all patients had elevated CRP and $75 \%$ had elevated PCT. Synovial fluid almost always had an inflammatory appearance and often was purulent, as also described in prior studies $(4,6-10,28)$. Positive gram staining results were reported in $80 \%$ of cases, and positive culture was reported in $93 \%$ of cases, similar to the rates from previous studies $(4,6-10)$.

In the literature, pneumococcal bacteremia was complicated by joint infection in $0.3 \%-0.6 \%$ of cases $(10,29,30)$; bacteremia was observed in $55 \%-100 \%$ of adults with pneumococcal SA $(4,6,8-10,16)$ and appeared to be more frequent when a prosthetic joint was infected (6). In our study, we observed bacteremia in $69 \%$ of cases of native SA and in $80 \%$ of cases of prosthetic joint infection. The frequency of documented concurrent bacteremia emphasizes the importance of obtaining blood cultures in addition to joint fluid cultures before initiating antimicrobial therapy. Isolation of pathogenic microorganisms from both synovial fluid and blood culture can be considered the gold standard for SA diagnosis.

Most reported pneumococcal SA strains for which antimicrobial susceptibility data were available were susceptible to penicillin $(6-10,28)$. A few strains with low- or high-level penicillin and ceftriaxone resistance have been reported in the literature $(6,7,10)$; in our study, $25 \%$ of the strains had low-level penicillin resistance, and $12.5 \%$ had low- or high-level ceftriaxone resistance. Regardless, the frequency of low-level $\beta$-lactam resistance decreased from $2005-2010$ to 2011-2016 ( $<<0.01)$. Despite the poor immunization coverage in this population, the decreased rate of resistance is related to a reduction in resistant serotypes, achieved by herd immunity. 
Radiography, computed tomography, scintigraphy, and magnetic resonance imaging can be useful to assess the presence and extent of bone and joint inflammation and destruction but cannot distinguish between infections and other causes of acute inflammatory arthritis (3). Septic inflammation of a joint also can lead to radionuclide uptake in scintigraphy (31). However, diagnosis of pyogenic sacroiliitis often was made on the basis of patient history, physical examination, and positive skeletal scintigraphy or computed tomography of the sacroiliac joint.

No consensus has been reached concerning the optimal duration of intravenous antimicrobial therapy and the role of switching to oral therapy $(3,28)$. The median duration reported in the literature ranged from 17-30.1 days for intravenous therapy and 30.6-49 days for oral antimicrobial agents $(4,6,8-10)$. The median duration of intravenous therapy in our study was shorter, 1-23 days with a mean of 5.5 days, but the overall duration of antimicrobial therapy was comparable to reports in the literature. In several studies, penicillin was the most commonly used antimicrobial drug, then third-generation cephalosporins; gentamicin rarely was used $(7,8,10,28)$. In contrast, $68.75 \%$ of cases in our study received a combination therapy of a $\beta$-lactam antimicrobial drug and gentamicin.

Antimicrobial therapy in the absence of drainage can be successful in certain patients. However, arthrotomy in combination with antimicrobial therapy typically is considered the best treatment for SA $(4,6-10)$. In our cohort, arthrotomy was performed in $46 \%$ of cases. In the literature, when information regarding management was available, joint drainage always was performed on patients with SA in a prosthetic joint. Several cases of pneumococcal prosthetic joint SA required extended courses of antimicrobial drugs or even lifetime antimicrobial therapy, open surgical drainage, and sometimes replacement of the prosthetic joint $(3,7,8,26,28)$.

Pneumococcal SA usually has a favorable prognosis when appropriate treatment is instituted rapidly $(3,28)$. In our study and others we reviewed, most patients recovered and achieved their initial joint range of motion or had only minor sequelae with mildly reduced range of motion $(7,9,10)$. Nevertheless, extensive physical damage sometimes was described (4), and mortality rates of up to $32 \%$ were reported in patients with pneumococcal SA (6$8,10,16)$. Risk of death appeared to be higher in cases of pneumococcal SA associated with bacteremia $(24 \%)$ than those without bacteremia (6\%) (15). In our study, 1 (7\%) patient died with SA infection caused by a strain with lowlevel penicillin resistance.

Because the prevalence of antimicrobial drug-resistant S. pneumoniae has increased, pneumococcal vaccination has become a greater focus for public health $(12,15,17$
21). In the Picardie region, and in France as a whole, both PCV13 and pneumococcal 23-valent polysaccharide vaccine (PPV23) are indicated in adults with underlying conditions that predispose them to pneumococcal disease $(15,17)$. In the Picardie Regional Pneumococcal Network, $82 \%(9 / 14)$ of patients with known vaccination status had not been vaccinated; of those, 5 (55.5\%) had underlying conditions that would have justified pneumococcal vaccination. Of the strains isolated, $60 \%$ are covered by either PCV13 or PPV23. Of the $40 \%$ not covered by either vaccine, 5 were $23 \mathrm{~B}$ serotype and 1 was the $24 \mathrm{~F}$ serotype. Although several studies have demonstrated the effectiveness of pneumococcal vaccines in preventing IPD in adults $(17,18,20,21)$, a large retrospective study of patients with pneumococcal SA reported $S$. pneumoniae serotypes $22 \mathrm{~F}$ and $12 \mathrm{~F}$, both of which are covered by PPV23, frequently occur (16), findings that emphasize the importance of following the immunization guidelines.

In June 2010, health authorities in France introduced PCV13 for children $<2$ years of age; older children with $\geq 1$ underlying conditions, such as innate or acquired immunodeficiency, malignancy, impaired splenic function, cochlear implants, cerebrospinal fluid leakage, or recurrent IPD; and adults at risk for pneumococcal infections, such as those with immunosuppression or history of splenectomy. According to studies in France, after the introduction of PCV13, the incidence of all IPD types decreased during $2008-2012$ by $20 \%$ in adults $16-64$ years of age and by $15 \%$ in patients $\geq 65$ years of age (17). Decreases in $S$. pneumoniae isolates with reduced antimicrobial sensitivity also were noted (15), but the frequency of serotypes not covered by the vaccine increased $(15,17)$.

In our study, serotype 23B in pneumococcal SA or IPD emerged 2 years after the introduction of PCV13 (data not shown), and these strains were always penicillin susceptible. The 2 patients in our study who had $S$. pneumoniae vaccination after splenectomy were not protected against infection by serotypes 23B and 24F. Our data are consistent with trends observed in other countries (32-35). For example, Germany and the United States report a rise in serotype 23B after implementation of PCV13 (32-35) and a high proportion of the 23B isolates displayed a low-level penicillin resistance. However, the serotype 23B strain we saw in the Picardie region was always penicillin-susceptible. If confirmed by future studies, 23B and 24F serotypes should be considered when developing next-generation PCVs (36).

In conclusion, the prevalence of pneumococcal SA in adults in the Picardie Regional Pneumococcal Network of France increased over the 5 years reported, apparently in relation to emergence of serotype 23B. Vaccination in the region might not comply fully with the current guidelines; $60 \%$ of the strains isolated from patients in this study are 
covered by PCV13 and PPV23, suggesting that these pneumococcal infections could have been prevented.

Authors' contributions: Y.E.S., A.D., V.S., J.S., and C.G. performed clinical examinations. J.P.E., A.B., M.E.H., C.P., F.R., and F.H. performed bacteriological diagnoses, E.V. serotyped the S. pneumoniae strains, and M.D. performed the statistical analysis. A.D. and F.H. drafted the manuscript. All authors read and approved the final manuscript.

\section{About the Author}

Mrs. Dernoncourt is an internal medicine resident at the University Hospital of Amiens-Picardie, Amiens, France. Her research interests include immune-related diseases and vaccine-preventable infections. Dr. Hamdad is a senior clinical microbiologist and $\mathrm{PhD}$ at the University Hospital of Amiens-Picardie, Amiens, France. Her research interests include emerging infectious diseases and antimicrobial resistance.

\section{References}

1. Mathews CJ, Weston VC, Jones A, Field M, Coakley G. Bacterial septic arthritis in adults. Lancet. 2010;375:846-55. https://doi.org/ 10.1016/S0140-6736(09)61595-6

2. García-Arias M, Balsa A, Mola EM. Septic arthritis. Best Pract Res Clin Rheumatol. 2011;25:407-21. https://doi.org/10.1016/ j.berh.2011.02.001

3. Goldenberg DL. Septic arthritis. Lancet. 1998;351:197-202. https://doi.org/10.1016/S0140-6736(97)09522-6

4. Dubost J-J, Soubrier M, De Champs C, Ristori J-M, Sauvezie B. Streptococcal septic arthritis in adults. A study of 55 cases with a literature review. Joint Bone Spine. 2004;71:303-11. https://doi.org/10.1016/S1297-319X(03)00122-2

5. Ryan MJ, Kavanagh R, Wall PG, Hazleman BL. Bacterial joint infections in England and Wales: analysis of bacterial isolates over a four year period. Br J Rheumatol. 1997;36:370-3. https://doi.org/10.1093/rheumatology/36.3.370

6. Raad J, Peacock JE Jr. Septic arthritis in the adult caused by Streptococcus pneumoniae: a report of 4 cases and review of the literature. Semin Arthritis Rheum. 2004;34:559-69. https://doi.org/10.1016/j.semarthrit.2004.04.002

7. James PA, Thomas MG; Paul A. James, Mark G. Thomas. Streptococcus pneumoniae septic arthritis in adults. Scand J Infect Dis. 2000;32:491-4. https://doi.org/10.1080/003655400458758

8. Ispahani P, Weston VC, Turner DP, Donald FE. Septic arthritis due to Streptococcus pneumoniae in Nottingham, United Kingdom, 1985-1998. Clin Infect Dis. 1999;29:1450-4. https://doi.org/10.1086/313526

9. Belkhir L, Rodriguez-Villalobos H, Vandercam B, Marot JC, Cornu O, Lambert M, et al. Pneumococcal septic arthritis in adults: clinical analysis and review. Acta Clin Belg. 2014;69:40-6. https://doi.org/10.1179/0001551213Z.00000000015

10. Ross JJ, Saltzman CL, Carling P, Shapiro DS. Pneumococcal septic arthritis: review of 190 cases. Clin Infect Dis. 2003;36:319-27. https://doi.org/10.1086/345954

11. Seng P, Vernier M, Gay A, Pinelli P-O, Legré R, Stein A. Clinical features and outcome of bone and joint infections with streptococcal involvement: 5-year experience of interregional reference centres in the south of France. New Microbes New Infect. 2016;12:8-17. https://doi.org/10.1016/j.nmni.2016.03.009
12. Dockrell DH, Whyte MKB, Mitchell TJ. Pneumococcal pneumonia: mechanisms of infection and resolution. Chest. 2012;142:482-91. https://doi.org/10.1378/chest.12-0210

13. Lynch JP III, Zhanel GG. Streptococcus pneumoniae: epidemiology, risk factors, and strategies for prevention. Semin Respir Crit Care Med. 2009;30:189-209. https://doi.org/ 10.1055/s-0029-1202938

14. Rueda AM, Serpa JA, Matloobi M, Mushtaq M, Musher DM. The spectrum of invasive pneumococcal disease at an adult tertiary care hospital in the early 21 st century. Medicine (Baltimore). 2010;89:331-6. https://doi.org/10.1097/MD.0b013e3181f2b824

15. Varon E. Epidemiology of Streptococcus pneumoniae. Med Mal Infect. 2012;42:361-5. https://doi.org/10.1016/ j.medmal.2012.04.002

16. Marrie TJ, Tyrrell GJ, Majumdar SR, Eurich DT. Rates of, and risk factors for, septic arthritis in patients with invasive pneumococcal disease: prospective cohort study. BMC Infect Dis. 2017;17:680. https://doi.org/10.1186/s12879-017-2797-7

17. Lepoutre A, Varon E, Georges S, Dorléans F, Janoir C, Gutmann L, et al.; Microbiologists of Epibac; ORP Networks. Impact of the pneumococcal conjugate vaccines on invasive pneumococcal disease in France, 2001-2012. Vaccine. 2015;33:359-66. https://doi.org/10.1016/j.vaccine.2014.11.011

18. Webber C, Patton M, Patterson S, Schmoele-Thoma B, Huijts SM, Bonten MJM; CAPiTA Study Group. Exploratory efficacy endpoints in the Community-Acquired Pneumonia Immunization Trial in Adults (CAPiTA). Vaccine. 2017;35:1266-72. https://doi.org/10.1016/j.vaccine.2017.01.032

19. Richard C, Le Garlantezec P, Lamand V, Rasamijao V, Rapp C. Anti-pneumococcal vaccine coverage for hospitalized risk patients: Assessment and suggestions for improvements [in French]. Ann Pharm Fr. 2016;74:244-51. https://doi.org/10.1016/ j.pharma.2015.10.007

20. Falkenhorst G, Remschmidt C, Harder T, Hummers-Pradier E, Wichmann O, Bogdan C. Effectiveness of the 23-valent pneumococcal polysaccharide vaccine (PPV23) against pneumococcal disease in the elderly: systematic review and meta-analysis. PLoS One. 2017;12:e0169368. https://doi.org/ 10.1371/journal.pone. 0169368

21. Bonten MJ, Huijts SM, Bolkenbaas M, Webber C, Patterson S, Gault S, et al. Polysaccharide conjugate vaccine against pneumococcal pneumonia in adults. N Engl J Med. 2015; 372:1114-25. https://doi.org/10.1056/NEJMoa1408544

22. Butler JC, Schuchat A. Epidemiology of pneumococcal infections in the elderly. Drugs Aging. 1999;15(Suppl 1):11-9. https://doi.org/10.2165/00002512-199915001-00002

23. Forestier E, Sordet C, Cohen-Solal J, Remy V, Javier RM, Kuntz JL, et al. Bone and joint infection due to Streptococcus pneumoniae in two immunocompetent adults. Joint Bone Spine. 2006;73:325-8. https://doi.org/10.1016/j.jbspin.2005.07.004

24. Riachy MA. Streptococcus pneumoniae causing septic arthritis with shock and revealing multiple myeloma. BMJ Case Rep. 2011;2011:bcr1220103664. 10.1136/bcr.12.2010.3664 https://doi.org/10.1136/bcr.12.2010.3664

25. Kalambokis GN, Christou L, Tsianos EV. Multiple myeloma presenting with an acute bacterial infection. Int J Lab Hematol. 2009;31:375-83. https://doi.org/10.1111/j.1751-553X.2009.01154.x

26. Bertani A, Drouin C, Demortière E, Gonzalez J-F, Candoni P, Di Schino M. A prosthetic joint infection caused by Streptococcus pneumoniae: a case report and review of the literature [in French]. Rev Chir Orthop Repar Appar Mot. 2006;92:610-4. https://doi.org/10.1016/S0035-1040(06)75921-9

27. Zhao J, Zhang S, Zhang L, Dong X, Li J, Wang Y, et al. Serum procalcitonin levels as a diagnostic marker for septic arthritis: a meta-analysis. Am J Emerg Med. 2017;35:1166-71. https://doi.org/10.1016/j.ajem.2017.06.014 
28. Baraboutis I, Skoutelis A. Streptococcus pneumoniae septic arthritis in adults. Clin Microbiol Infect. 2004;10:1037-9. https://doi.org/10.1111/j.1469-0691.2004.00968.x

29. Gransden WR, Eykyn SJ, Phillips I. Pneumococcal bacteraemia: 325 episodes diagnosed at St Thomas's Hospital. Br Med J (Clin Res Ed). 1985;290:505-8. https://doi.org/10.1136/ bmj.290.6467.505

30. Burman LA, Norrby R, Trollfors B. Invasive pneumococcal infections: incidence, predisposing factors, and prognosis. Rev Infect Dis. 1985;7:133-42. https://doi.org/10.1093/clinids/7.2.133

31. Bhattarai A, Nakajima T, Sapkota S, Arisaka Y, Tokue A, Yonemoto Y, et al. Diagnostic value of 18F-fluorodeoxyglucose uptake parameters to differentiate rheumatoid arthritis from other types of arthritis. Medicine (Baltimore). 2017;96:e7130. https://doi.org/10.1097/MD.0000000000007130

32. van der Linden M, Falkenhorst G, Perniciaro S, Imöhl M. Effects of infant pneumococcal conjugate vaccination on serotype distribution in invasive pneumococcal disease among children and adults in Germany. PLoS One. 2015;10:e0131494. https://doi.org/10.1371/ journal.pone. 0131494

33. van der Linden $M$, Perniciaro $S$, Imöhl M. Increase of serotypes $15 \mathrm{~A}$ and 23B in IPD in Germany in the PCV13 vaccination era. BMC Infect Dis. 2015;15:207. https://doi.org/10.1186/s12879-015-0941-9
34. Steens A, Bergsaker MA, Aaberge IS, Rønning K, Vestrheim DF. Prompt effect of replacing the 7-valent pneumococcal conjugate vaccine with the 13-valent vaccine on the epidemiology of invasive pneumococcal disease in Norway. Vaccine. 2013;31:6232-8. https://doi.org/10.1016/j.vaccine.2013.10.032

35. Richter SS, Diekema DJ, Heilmann KP, Dohrn CL, Riahi F, Doern GV. Changes in pneumococcal serotypes and antimicrobial resistance after introduction of the 13-valent conjugate vaccine in the United States. Antimicrob Agents Chemother. 2014;58:6484-9. PubMed https://doi.org/10.1128/ AAC.03344-14

36. Ouldali N, Levy C, Varon E, Bonacorsi S, Béchet S, Cohen R, et al.; French Pediatric Meningitis Network. Incidence of paediatric pneumococcal meningitis and emergence of new serotypes: a timeseries analysis of a 16-year French national survey. Lancet Infect Dis. 2018;18:983-91. https://doi.org/10.1016/ S1473-3099(18)30349-9

Address for correspondence: Amandine Dernoncourt, Amiens-Picardie University Medical Center, Department of Internal Medicine, Place Victor Pauchet, F-80054 Amiens CEDEX 01, France; email: amandine.dernoncourt@wanadoo.fr

\section{etymologia}

\section{Edwardsiella tarda}

\section{Ronnie Henry}

I 1965, a group of CDC researchers described a species of gramnegative, facultatively anaerobic bacteria in the family Enterobacteriaceae, which they named Edwardsiella (for CDC microbiologist Philip R. Edwards) tarda (Latin, "slow," referring to biochemical inactivity and the fact that it ferments few carbohydrates). These organisms infect a variety of fish, reptiles, and amphibians and are opportunistic pathogens for humans.
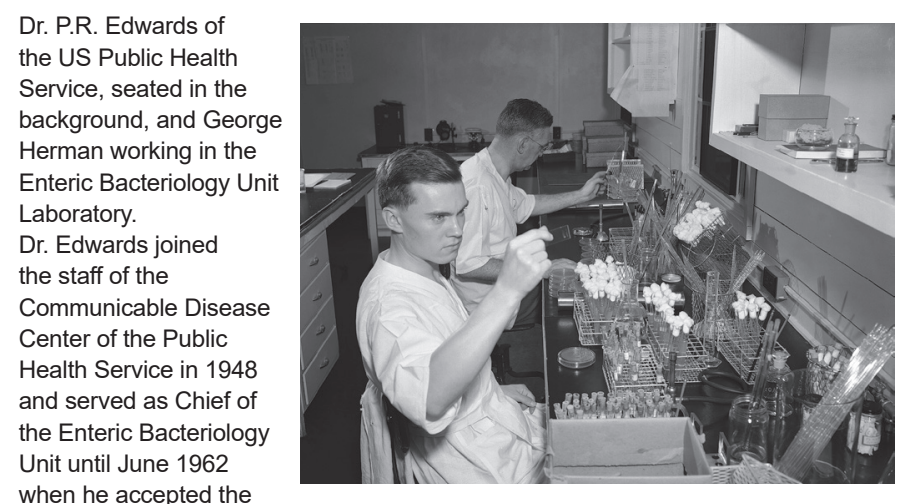

post of Chief of the Bacteriology Section at CDC. Image source, Public Health Image Library.

\section{Sources}

1. Ewing WH, McWhorter AC, Escobar MR, Lubin AH. Edwardsiella, a new genus of Enterobacteriaceae based on a new species, E. tarda. Int Bull Bacteriol Nomencl Taxon. 1965;15:33-8. https://doi.org/10.1099/00207713-15-1-33

2. Abbott SL, Janda JM. The genus Edwardsiella. In: Dworkin M, editor. The prokaryotes. New York: Springer; 2006. p. $72-89$.

Address for correspondence: Ronnie Henry, Centers for Disease Control and Prevention, 1600 Clifton Rd NE, Mailstop E28, Atlanta, GA 30329-4027, USA; email: boq3@cdc.gov

DOI: https://doi.org/10.3201/eid2510.ET2510 